\title{
Correlation between Diabetes Mellitus Onset with Diabetic Nephropathy Case of the In-Patients Treated in RS Muhammadiyah Ahmad Dahlan Kediri
}

\author{
Satria Candra Kusuma1, Muh. Masykur AG² \\ ${ }^{1}$ Doctor of RS Muhammadiyah Ahmad Dahlan Kediri, \\ 2Director of Psycho Care Clinic Malang \\ Email : masyafa85@gmail.com \\ Received : August $21^{\text {th }}$ 2019. Revised : Sept 15 ${ }^{\text {th }}$ 2019. Published: Dec $20^{\text {th }} 2019$ \\ DOI : https://doi.org/10.22219/sm.Vol15.SMUMM2.9583
}

\begin{abstract}
The average number of diabetes mellitus patients who underwent hospitalization in RS Muhammadiyah Ahmad Dahlan Kediri reached $11.6 \%$ per month. The age range of the patients was between 5-15 years. They usually suffered from complications such as DM nephropathy, hypertension and hyperglycemia, that this fact should be inspected further. This study was intended to cover as to how significant is the correlation between diabetes mellitus onset and the case of diabetic nephropathy suffered by patients. The design of this study was cross sectional correlative descriptive. The sample of this study was the DM in-patients with the complication of diabetic nephropathy taken using total sampling. Spearman Rank was used as the data analysis technique. This study has found that $49(84.48 \%)$ out of 58 diabetes mellitus patients were suffered from diabetic nephropathy too. Meanwhile, according to the result of hypothesis test, the r-count value was 0.743 and the significance rate was 0.000 , which mean that there was a relation between the variable of diabetes mellitus onset and variable of diabetic nephropathy case occurred to the in-patients of RS Muhammadiyah Ahmad Dahlan Kediri.
\end{abstract}

Keywords: Correlation, Diabetes Mellitus, Diabetic Nephropathy.

Copyright (C) 2019, First Author et al This is an open access article under the CC-BY-SA license

\section{INTRODUCTION}

Diabetes Mellitus (DM) is a kind of carbohydrate, fat, and chronic protein metabolism disruption caused by the damage or the lack of insulin secretion, leading the patients to hyperglycemia (Pratama, Chasani \& Santoso, 2013). Most of the diabetes mellitus pathologic depictions can be linked to the decrease of cell's activities in utilizing glucose, escalation of fat metabolism and reduction of protein in the tissue Satria (Decroli \& Afriwardi, 2018).

It has been assumed by World Health Organization (WHO) that prevalence of diabetes mellitus in the whole world will continuously be increasing (Shaw et al., 2009). According to Sistem Informasi Rumah Sakit (SIRS) of 2010-2011, Diabetes Mellitus was ranked $5^{\text {th }}$ of the top 10 of non- 
communicable diseases that lead to hospitalization. The percentage was $1.92 \%$ in 2009 and $26 \%$ in 2010 (Kemenkes RI, 2012).

In 2000, percentage of Diabetes Mellitus prevalence was approximately $0.19 \%$ for the patient age of $<20$ years, $8.6 \%$ for the age of $>20$ years and $20.1 \%$ for the age of $>65$ years. This percentage was applicable for both men and women, except for the age range of $>60$ years in which the amount of male patients is higher (Waspadji, 2005). Laporan Nasional of 2007confirmed that, in the suburban of Jawa Timur, $6.8 \%$ of Diabetes Mellitus prevalence was occurred mainly to the people who don't attend school, unemployed housewives, employees and entrepreneurs (Kemenkes RI, 2008).

Ministry of Health (2015) stated that the causes of diabetes mellitus include overweight, excessive stress, DM history from family, particular conditions occurred to woman, smoke addiction, excessive high-sugar and high-fat food consumption, avoidance of skin blackening and fries consumption. More than $85 \%$ of type $2 \mathrm{DM}$ patients are found to be overweight. Meanwhile, prolonged stress may increase epinephrine and cortisol which are known as the enhancer of blood sugar and energy (that should be utilized to perform activities). But, if the amount of blood sugar grows continuously, or unbalanced, it will bring negative effect to human's body.

Heredity factor can be one of the causes of diabetes mellitus. If a person's parents have ever been diagnosed to be suffered from type 2 diabetes, it is most likely that the person will be suffered from diabetes. A woman that is suffered from polycystic ovary syndrome is more probably to undergo diabetes. This syndrome can be defined as hormonal imbalance which causes irregular menstruation period. American entity has noted that the risk of diabetes mellitus will be raised up to $22 \%$ for the active smokers. Excessive consumption to sugary and lardy foods, as well as the lack of Vitamin D intake, will also trigger diabetes mellitus (Kemenkes, 2015).

Uncontrolled diabetes mellitus will cause either micro vascular or macro vascular chronic complications. Manifestations of macro vascular complications are coronary heart, cerebral thrombosis and gangrene. Meanwhile, diseases caused by micro vascular complications include diabetic retinopathy and diabetic nephropathy (Waspadji, 2005). Diabetic Nephropathy is a kidney disease which usually follows the next stadium of diabetes mellitus, starting from hyper filtration, renal hypertrophy,mikro-albuminuria, hypertension and proteinuria, which is indicated by reduction of renal function and the existence of kidney failure disease (Hartanto et al., 2000).

According to Bethesda (2002) from National Institute of Health, diabetic nephropathy was found in $35-45 \%$ of diabetes mellitus patients, and $40 \%$ of diabetic nephropathy prevalence was the culprit of kidney failure. Almost sixty percent of hypertension and diabetes mellitus patients in Asia are suffered from diabetic nephropathy. $18.8 \%$ of them are suffered from macro albuminuria which is the first stadium of nephropathy. Clinically, diabetic nephropathy is indicated by progressive proteinuria escalation, degradation of Laju Filtrasi Glomerulus (LFG)/Glomerulus Filtration Rate and hypertension. Patients of diabetic nephropathy are more prone to cardiovascular (Pratama, Chasani \& Santoso, 2013). 
Diabetic Nephropathy is most probably due to the genetics, relating to certain chromosome. In fact, the onset and development of kidney disease (which is caused by diabetes mellitus) are quite varied. A descriptive researchon the distribution of chronic complication caused by vascular disruption suffered by type 2 diabetes mellitus patients which are being treated in RSUD Dr. Soetomo Surabaya, has found that $58.4 \%$ of the patients were suffered from nephropathy, while $32.1 \%$ of it were suffered from retinopathy and the $10.5 \%$ were suffered from neuropathy(Amalia, 2010). Pratama et al (2013) have found that there is a significant relation between diabetes mellitus onset and the case of diabetic nephropathy. Meanwhile, a research conducted by Markum \& Galastri (2004) implies that sickness duration and the retinopathy suffered by diabetes mellitus patients are significantly related to the case of diabetic nephropathy.

Due to the above conditions, this research studied the relation between diabetes mellitus onset and diabetic nephropathy of the in-patients treated in RS Muhammadiyah Ahmad Dahlan Kediri.

\section{METHODS}

This was a correlative descriptive study with Cross Sectional approach. The population of this study was the data in the form of diabetes mellitus in-patients (suffering from diabetic nephropathy complication) medical record provided by RS Muhammadiyah Ahmad Dahlan Kediri for August until December 2018. The sample data (belonging to DM patients with diabetic nephropathy complication) were secondary and were taken using total sampling method. The inclusion criteria included complete medical record, as in patient's registration number, age, gender, blood pressure, blood glucose level, total cholesterol level, HDL, LDL, and triglyceride level. The exclusion criterion was diabetes mellitus patients with diabetic nephropathy and heart infection/ heartbreak. The study was conducted in August until December using Spearman Rank analysis method with significance level of 0.01 .

\section{FINDINGS AND DISCUSSION}

The samples were 58 diabetes mellitus in-patients suffered from diabetic nephropathy complication and treated in RS Muhammadiyah Ahmad Dahlan Kediri. The results of this study included the number of patients based on month, occurrence of diabetic nephropathy, hypertension, duration of the DM sickness and the relation between diabetes mellitus onset and diabetic nephropathy occurrence. The results of this research were than processed and tabulated in the form of this frequency table. 
Table 1. Distribution of Amount Characteristic of Diabetes Mellitus Patients

\begin{tabular}{cccc}
\hline No. & Month & Frequency $(f)$ & Percentage $(\%)$ \\
\hline 1 & August & 11 & $18.96 \%$ \\
\hline 2 & September & 10 & $17.24 \%$ \\
\hline 3 & October & 8 & $13.81 \%$ \\
\hline 4 & November & 14 & $24.13 \%$ \\
\hline 5 & December & 15 & $25.86 \%$ \\
\hline & Total & 58 & $100 \%$ \\
\hline
\end{tabular}

It can be seen trough the table that the amount of diabetes mellitus patient who were hospitalized in di RS Muhammadiyah Ahmad Dahlan Kedirireached its peakin December, which was 15 or $25.86 \%$.

Table 2. Distribution of Amount Characteristic of Patients Based on Hyperglycemia Complication

\begin{tabular}{ccccc}
\hline No & Month & Amount of Patient & $\begin{array}{c}\text { Frequency }(f) \text { of } \\
\text { Hyperglycemia }\end{array}$ & Percentage (\%) \\
\hline 1 & August & 11 & 8 & $21.62 \%$ \\
\hline 2 & September & 10 & 6 & $16.21 \%$ \\
\hline 3 & October & 8 & 5 & $13.53 \%$ \\
\hline 4 & November & 14 & 9 & $24.32 \%$ \\
\hline 5 & December & 15 & 9 & $24.32 \%$ \\
\hline & Total & 58 & 37 & $100 \%$ \\
\hline
\end{tabular}

From the Table 2, we can see that,out of 58 diabetes mellitus patients underwent hospitalization in RS Muhammadiyah Ahmad Dahlan Kediri, 37 or $63.79 \%$ of them are suffered from hyperglycemia, and this case was occurred in November and December with calculation of 9 (or $24.32 \%$ ) cases for eachmonth.

Table 3. Distribution of Amount Characteristic of Patients Based on Diabetic Nephropathy Complication

\begin{tabular}{ccccc}
\hline No & Month & Amount of Patient & $\begin{array}{c}\text { Frequency }(f) \text { of } \\
\text { Diabetic } \\
\text { Nephropathy }\end{array}$ & Percentage (\%) \\
\hline 1 & August & 11 & 9 & $18,36 \%$ \\
\hline 2 & September & 10 & 8 & $16,32 \%$ \\
\hline 3 & October & 8 & 7 & $14,28 \%$ \\
\hline 4 & November & 14 & 12 & $24,48 \%$ \\
\hline 5 & December & 15 & 13 & $26,56 \%$ \\
\hline & Total & 58 & 49 & $100 \%$ \\
\hline
\end{tabular}

Through the Table 3, we can see that, out of 58 diabetes mellitus patients underwent hospitalization in RS Muhammadiyah Ahmad Dahlan Kediri, 49 or $84.48 \%$ of them are suffered from diabetic nephropathy, and this case was occurred in December with calculation of 13 (or $26.32 \%$ ) patients. 
Table 4. Distribution of Amount Characteristic of Patients Based on Hypertension Complication

\begin{tabular}{ccccc}
\hline No & Month & Amount of Patient & $\begin{array}{c}\text { Frequency }(f) \text { of } \\
\text { Hypertension }\end{array}$ & Percentage (\%) \\
\hline 1 & August & 11 & 7 & $22,58 \%$ \\
\hline 2 & September & 10 & 5 & $16,12 \%$ \\
\hline 3 & October & 8 & 4 & $12,92 \%$ \\
\hline 4 & November & 14 & 7 & $22,58 \%$ \\
\hline 5 & December & 15 & 8 & $25,80 \%$ \\
\hline & Total & 58 & 31 & $100 \%$ \\
\hline
\end{tabular}

Through the Table 4, we can see that, out of 58 diabetes mellitus patients underwent hospitalization in RS Muhammadiyah Ahmad Dahlan Kediri, 31 or $53.44 \%$ of them are suffered from hypertension, and this case was occurred in December with calculation of 8 (or 25.80\%) patients.

Table 5. Distribution of Amount Characteristic of Patients Based on Diabetes Mellitus Sickness Duration

\begin{tabular}{|c|c|c|c|c|c|}
\hline \multirow{3}{*}{ No } & \multirow{3}{*}{ Month } & \multirow{3}{*}{$\begin{array}{c}\text { Amount of } \\
\text { Diabetic Nephropathy } \\
\text { Patients }\end{array}$} & \multicolumn{3}{|c|}{$\begin{array}{c}\text { Frequency }(f) \text { of } \\
\text { DM Sickness Duration }\end{array}$} \\
\hline & & & $<5$ & $5-10$ & $10-15$ \\
\hline & & & yr. & yr. & yr. \\
\hline 1 & August & 9 & 2 & 2 & 5 \\
\hline 2 & September & 8 & 1 & 3 & 4 \\
\hline 3 & October & 7 & 1 & 2 & 4 \\
\hline 4 & November & 12 & 2 & 4 & 6 \\
\hline 5 & December & 13 & 3 & 4 & 6 \\
\hline & Total $(f)$ & 49 & 9 & 15 & 25 \\
\hline & Percentage $(\%)$ & $100 \%$ & $18.37 \%$ & $30.61 \%$ & $51.02 \%$ \\
\hline
\end{tabular}

From the Table 5, we can see that, out of 49 diabetes mellitus patients with diabetic nephropathy, who underwent hospitalization in RS Muhammadiyah Ahmad Dahlan Kediri, have generally been enduring hypertension for 10-15 years, with the calculation of 25 (or $51.02 \%$ ) patients.

Table 6. Distribution of Amount Characteristic of Patients Based on DM History from Family

\begin{tabular}{ccccc}
\hline No & Month & Amount of Patient & $\begin{array}{c}\text { Frequency }(f) \\
\text { ofDM History } \\
\text { from Family }\end{array}$ & Percentage (\%) \\
\hline 1 & August & 11 & 5 & $17.24 \%$ \\
\hline 2 & September & 10 & 5 & $17.24 \%$ \\
\hline 3 & October & 8 & 4 & $13.81 \%$ \\
\hline 4 & November & 14 & 8 & $27.58 \%$ \\
\hline 5 & December & 15 & 7 & $24.13 \%$ \\
\hline & Total & 58 & 29 & $100 \%$ \\
\hline
\end{tabular}


From the Table 6, we can see that, out of 58 diabetes mellitus patients underwent hospitalization in RS Muhammadiyah Ahmad Dahlan Kediri, 29 or 50\% of them were gained Diabetes Mellitus due to family history, and this fact was detected mostly in the in-patients enrolled in November with calculation of 8 (or $27.58 \%$ ) patients.

Tabel 7. Spearman Rank Correlation Test on Diabetes Melitus with Diabetic Nephropathy Case

\begin{tabular}{|c|c|c|c|c|}
\hline \multicolumn{3}{|c|}{ Correlations } & $\begin{array}{l}\text { Diabetes } \\
\text { Mellitus }\end{array}$ & $\begin{array}{c}\text { Diabetic } \\
\text { Nephropathy }\end{array}$ \\
\hline \multirow[t]{6}{*}{ Spearman's rho } & \multirow[t]{3}{*}{ Diabetes Mellitus } & Correlation Coefficient & 1.000 & $.743^{* *}$ \\
\hline & & Sig. (2-tailed) & . & .000 \\
\hline & & $\mathrm{N}$ & 58 & 58 \\
\hline & \multirow{3}{*}{$\begin{array}{l}\text { Diabetic } \\
\text { Nephropathy }\end{array}$} & Correlation Coefficient & $.743^{* *}$ & 1.000 \\
\hline & & Sig. (2-tailed) & .000 & . \\
\hline & & $\mathrm{N}$ & 58 & 58 \\
\hline
\end{tabular}

**. Correlation is significant at the 0.01 level (2-tailed).

According to Table 7, the r-count value as 0.743 and the significance was 0.000 . Due to the fact that the $r$-count value was higher than $r$-table value $(0.743>0.432)$, and that the significance value was less than $0.05(0.000<0.01)$, then it is safe to say that there was a relation between diabetes mellitus onset occurred to the in-patients of RS Muhammadiyah Ahmad Dahlan Kediri and diabetic nephropathy case.

It was found through the result that several of the patients enduring diabetes mellitus also had diabetic nephropathy, hypertension and hyperglycemia. This fact was even worsened by the factor of sickness duration and the DM history obtained from family. During Augustus 2018, there were 11 diabetes mellitus patients and 9 of them (81.81\%) were suffering from diabetic nephropathy, while 7of them $(63.63 \%)$ were suffering from hypertension and 8 of them $(72.72 \%)$ were suffering from hyperglycemia. Two of the patients $(18.18 \%)$ endured diabetes mellitus for less than 5 years, the other two $(18.18 \%)$ had been enduring diabetes mellitus for 5-10 years, while five of them (45.45\%) had been enduring diabetes mellitus for 10-15 years and the other five of the patients $(45.45 \%)$ were proven to be diagnosed with diabetes mellitus from their relatives who also suffered from diabetes mellitus.

In September 2018, there were 10 diabetes mellitus patients and 8 of them $(80 \%)$ were suffering from diabetic nephropathy, while 5 of them (50\%) suffering from hypertension and 6 of them $(60 \%)$ were suffering from hyperglycemia. One of the patients $(10 \%)$ endure diabetes mellitus for less than 5 years, three of them (30\%) have been enduring diabetes mellitus for 5-10 years, while four of them $(40 \%)$ have been enduring diabetes mellitus for 10-15 years and five of the patients $(50 \%)$ were proven to be diagnosed with diabetes mellitus from their relatives who also suffered from diabetes mellitus.

In November 2018, there were 14 diabetes mellitus patients and 12 of them $(85.71 \%)$ were suffering from diabetic nephropathy, while 7 of them (50\%) suffering from hypertension and 9 of them 
$(64.28 \%)$ were suffering from hyperglycemia. Two of the patients $(14,28 \%)$ endure diabetes mellitus for less than 5 years, four of them (28.57\%)have been enduring diabetes mellitus for 5-10 years, while six of them (40\%) have been enduring diabetes mellitus for 10-15 years and eight of the patients $(57.14 \%)$ were proven to be diagnosed with diabetes mellitus from their relatives who also suffered from diabetes mellitus.

In December 2018, there were 15 diabetes mellitus patients and 13 of them (86.66\%) were suffering from diabetic nephropathy, while 8 of them (53.33\%) suffering from hypertension and 9 of them $(60 \%)$ were suffering from hyperglycemia. Three of the patients $(20 \%)$ endure diabetes mellitus for less than 5 years, four of them $(26.66 \%)$ have been enduring diabetes mellitus for 5-10 years, while six of them (40\%) have been enduring diabetes mellitus for 10-15 years and seven of the patients $(46.66 \%)$ were proven to be diagnosed with diabetes mellitus from their relatives who also suffered from diabetes mellitus.

Those facts implied that, partially, the case of diabetes mellitus in every patient who attended the hospital (based on month) was always followed by diabetic nephropathy complication, as well as hypertension and hyperglycemia. $49(84.48 \%)$ out of 58 diabetes mellitus patients were enduring diabetic nephropathy. This fact was underlined by the result of Spearman Rank hypothesis test with $\mathrm{r}$-count value of 0.743 and significance value of 0.000 . Thus, it can be said that there was a relation between variable of diabetes mellitus onset (suffered by in-patients of RS Muhammadiyah Ahmad Dahlan Kediri) and diabetic nephropathy case.

\section{CONCLUSION}

The result of this study implies that, out of 58 diabetes mellitus patients, $49(84.48 \%)$ were suffered from diabetic nephropathy. It is underlined by the result of Spearman Rank hypothesis test with rcount value of 0.743 and significance value of 0.000 . Thus, it can be said that there was a relation between variable of diabetes mellitus onset (suffered by in-patients of RS Muhammadiyah Ahmad Dahlan Kediri) and diabetic nephropathy case.

Suggestion: A deeper and more sophisticated research is needed regarding correlation between diabetes mellitus and several other diabetes mellitus complication predictors needs to be conducted, which means that the focus of the future result should not be limited only on the relation between DM and diabetic nephropathy, hypertension and hyperglycemia, based on the factors of sickness duration and family history. 


\section{REFERENCES}

Amalia, R. 2010. Gambaran Distribusi Komplikasi Kronik Gangguan Vaskuler pada Penderita Diabetes Mellitus Tipe 2 di Instalasi Rawat Inap RSUD Dr. Soetomo Surabaya Periode Waktu 1 April 2010-30 Juni 2010. Skripsi. Surabaya: Universitas Airlangga.

Hartanto H, Setiawan A, Bani AP, et al. 2000. Kamus Kedokteran Dorland. Edisi 29. Jakarta: EGC.

Kemenkes RI. 2015. Kenali Kebiasaan Penyebab Diabetes. Onlie: www.kemenkes.go.id. Diakses 29 Juni 2019.

Kementerian Kesehatan RI. 2008. Laporan Nasional 2007. Jakarta: Badan Penelitian dan Pengembangan Kesehatan Dasar Departemen Kesehatan Republik Indonesia.

Kementrian Kesehatan RI. 2012. Buletin Jendela Data dan Informasi Kesehatan, Penyakit Tidak Menular. Jakarta: Pusat Data dan Informasi Kemenkes RI.

Markum, H.M.S \& Galastri, M. 2004. Diabetic Nephropathy Among Type 2 Diabetes Mellitus Patients in Dr. Cipto Mangunkusumo Hospital. Med J Indones, Vol. 13, No. 3. JuliSeptember 2004.

Pratama, Aulia A.Y; Chasani, S \& santoso. 2013. Korelasi Lama Diabetes Melitus Terhadap Kejadian Nefropati Diabetik: Studi Kasus di Rumah Sakit Dokter Kariadi Semarang. Jurnal Media Medika Muda, Volume 2, Edisi 2, September 2013.

Satria ES, H; Decroli, E. \& Afriwardi. 2018. Faktor Risiko Pasien Nefropati Diabetik yang Dirawat di Bagian Penyakit Dalam RSUP Dr. M. Djamil Padang. Online: http://jurnal.fk.unand.ac.id. Diakses 29 Juni 2019.

Waspadji, S. 2005. Diabetes Mellitus: Mekanisme Dasar dan Pengelolaannya yang Rasional. Jakarta: Fakultas Kedokteran Universitas Indonesia. 